\title{
Peran Keluarga dalam Menumbuhkan Karakter Peduli Lingkungan bagi Anak Remaja
}

\author{
Jolya Wattimena ${ }^{1}$, Novita L. Sahertian ${ }^{2}$, Niechen J Revallo ${ }^{3}$ \\ Institut Agama Kristen Negeri Ambon \\ niken.revallo@gmail.com
}

\begin{abstract}
Environmental care character education in the family is the education that teaches children to get to know the environment which aims to increase children's awareness and love for their environment. There are several indicators of environmental care that must be applied in the family, namely; a) maintaining the cleanliness of the home environment, b) maintaining plants properly without stepping on or damaging them, c) throwing garbage in the right place. The purpose of this paper is to provide a description of growing children's character t be able to maintain, preserve and care for the environment for teenagers who are still far from what is expected or still lack the lack of value in terms of roles and responsibilities as parents that still exist to shape and build good children character. This lack $f$ parental attention and assistance to the child cause the child's character to decline which has an impact on attitudes and behavior in his daily life, both for himself and the environment in which he is located.
\end{abstract}

Keywords: character; environment care; family role; youth

\begin{abstract}
Abstrak: Pendidikan karakter peduli lingkungan dalam keluarga adalah pendidikan yang mengajarkan anak untuk mengenal lingkungan yang bertujuan untuk meningkatkan kesadaran dan kecintaan anak terhadap lingkungannya. Adapun beberapa indikator sikap peduli lingkungan yang harus diterapkan dalam keluarga yaitu antara lain: a) menjaga kebersihan lingkungan rumah, b) memelihara tumbuhtumbuhan dengan baik tanpa menginjak atau merusaknya, c) membuang sampah tepat pada tempatnya. Tujuan dari tulisan ini memberikan uraian dalam menumbuhkan karakter anak untuk dapat menjaga, melestarikan dan peduli terhadap lingkungan bagi Anak remaja yang masih jauh dari apa yang diharapkan atau masih kurangnya nilai dari sisi peran dan tanggung jawab sebagai orang tua untuk membentuk dan membangun karakter Anak yang baik. Kurangnya perhatian dan pendampingan orang tua terhadap Anak inilah, yang mengakibatkan karakter Anak merosot yang berdampak pada sikap dan tingkah laku dalam keseharian hidupnya, baik untuk diri sendiri maupun terhadap Lingkungan dimana la berada.
\end{abstract}

Kata Kunci: karakter; peduli lingkungan; peran keluarga; remaja

\section{Pendahuluan}

Lingkungan merupakan tempat di mana seorang anak tumbuh dan berkembang, sehingga lingkungan banyak berperan dalam membentuk kepribadian dan karakter seseorang. Bagi kebanyakan anak, lingkungan keluarga merupakan lingkungan yang mempengaruhi perkembangan anak, setelah itu sekolah dan kemudian masyarakat. Keluarga dipandang sebagai lingkungan dini yang dibangun oleh orang tua dan orang-orang terdekat. Setiap keluarga selalu berbeda dengan keluarga lainnya, dalam hal ini yang berbeda misalnya cara mendidik keluarga, keadaan ekonomi keluarga, nilai-nilai, dan kebiasaan yang turun temurun yang secara tidak sadar akan akan membentuk karakter anak. 
Keluarga memiliki pengaruh yang amat besar dalam pembentukan pondasi kepribadian anak. Keluarga yang gagal membentuk kepribadian anak biasanya adalah keluargayang penuh dengan konflik atau tidak bahagia. Tugas berat para orang tua adalah meyakinkan fungsi keluarga mereka benar-benar aman, nyaman bagi anak-anak mereka. Rumah adalah surga bagi anak, dimana mereka dapat menjadi cerdas, berbakti, dan tentu saja tercukupi lahir dan bathinnya.

Implementasi pembentukan karakter seoarang anak harus didukung oleh semua lembaga pendidikan termasuk lingkungan keluarga. Menurut Bussard Keluarga merupakan lingkungan sosial yang sangat dekat hubungannya dengan seseorang. Di keluarga seseorang dibesarkan, diberi tempat tinggal, berinteraksi satu dengan yang lain, dibentuknya nilai-nilai, pola pemikiran, kebiasaan dan berfungsi sebagai saksi segenap budaya luar dan mediasi hubungan anak dengan lingkungannya. Keluarga bagi seorang anak merupakan lembaga Pendidikan Non-Formal pertama, dimana mereka hidup, berkembang, dan matang. Di dalam sebuah keluarga seorang anak pertama kali diajarkan pada Pendidikan, dari pendidikan dalam keluarga tersebut anak mendapatkan pengalaman, kebiasaan, ketrampilan berbagai sikap dan bermacam-macam ilmu pengetahuan.

Peran orang tua terhadap anak sangat penting, tetapi tidak semua orang tuamelaksanakan tugas dan tanggung jawab itu secara baik dan benar. Peran orang tua ada yang positif dan ada juga yang negatif. Ada orang tua yang sudah dapat melaksanakan perannya dalam membina, membentuk, dan membangun karakter anak secara baik dan benar, dan menghasilkan anak yang peduli terhadap lingkungan. Menurut Keller lingkungan dapat dipertimbangkan sebagai kondisi total yang mengelilingi sebuah lingkungan individu atau komunitas. Lingkungan dapat didefinisikan meliputi dua bagian: yang pertama, kondisi; kondisi fisik seperti: udara, air, daratan, lautan, tumbuh-tumbuhan, binatang yang memberikan efek / dampak pertumbuhan dan perkembangan dari sebuah individu atau sebuah komunitas dan yang kedua Aspek sosial dan budaya seperti etika, ekonomi, estetika yang memberikan efek / dampak kepada sifat (behavior)sebuah individu atau komunitas (Roberth J. Kodoatie; 2003).

Dalam pandangan Kristen manusia dan Lingkungan (alam/bumi) adalah bagian yang integral dari sebuah proses penciptaan. Manusia dan alam adalah sama-sama ciptaan Tuhan. Proses penciptaan baik manusia maupun alam, semuanya mengarah pada tujuan Allah sendiri yakni "Semua baik adanya'". Bumi diciptakan Allah agar seluruh ciptaan hidup didalamnya, sebagaimana yang disaksikan dalam Alkitab. Manusia sendiri mendapat Kuasa dari Allah untuk mengelolah dan memanfaatkan alam ini. Kekuasaan yang diberikan Allah kepada manusia bukanlah kekuasaan yang semata-mata, tetapi kekasaan yang diberikan adalah merupakan suatu penugasan segabai mitra Allah dalam menjaga dan melestariakn ciptaan-Nya dan bukan untuk merusak ciptaan Tuhan.

Realia yang terjadi dewasa ini, alam yang merupakan ciptaan Allah bukan dijaga dengan baik oleh manusia yang merupakan mitra Allah, tetapi malah di rusak oleh manusia akibat kekuasaan yang manusia terima dari Allah itu sendri. Lingkungan tidak dianggap lagi sebagai bagian integral dari manusia melainkan sebaliknya, lingkungan dianggap sebatas materi untuk memenuhi kebutuhan manusia semata sehingga terjadilah perilaku merusak lingkungan dari manusia yang cukup parah. Akibatnya ialah Manusia hidup di planet bumi yang kian parah dan rusak, manusia sendiri yang menjadi salah satu penyebab utama terjadinya krisis lingkungan dengan pola-pola hidup tidak ramah lingkungan. 
Di Indonesia permasalahan lingkungan cukup variatif. Kerusakan lingkungan yang terjadi misalnya, pencemaran pada sungai-sungai sehingga menurunya kadar air, pembuangan limbah rumah tangga, limbah pabrik yang tidak dikelola dengan baik, lingkungan yang rusak karena terjadi pencemaaran udara yang dihasilkan oleh industri-industri maupun kendaraan bermotor dan juga terjadinya penggundulan hutan yang mengakibatkan berkurangnya satwa-satwa bahkan yang lebih marak saat ini adalah kerusakan lingkungan yang diakibatkan oleh pencemaran akibat sampah yang dibuang sembarangan (Rachmad K.dwi Susilo, 2009: 70-73) Salah satu contoh permasalahan lingkungan yang banyak dialami adalah mengenai sampah. Permasalahan lingkungan yang terjadi akibat sampah disebabkan Oleh perilaku manusia yang membuang sampah sembarangan. Sehingga mengakibatkan lingkungan tidak bersih, berbau tidak sedap, menimbulkan berbagai macam penyakit, mencemarkan air, tanah dan lainnya.

Permasalahan Lingkungan ini juga terjadi pada daerah kota ambon dan bahkan pada beberapa jemaat dalam Kota Ambon, contohnya pada Jemaat GPM Eden kudamati sektor Piston, salah satu Jemaat yang mempunyai wilayah bergelombang, bergunung, dan juga didominasi oleh daerah-daerah berbukit dan berlereng sehingga di dapati sebagian besar pemukiman rumah masyarakat berada pada areacuram. Pemukiman rumah yang dibangun di area ini membuat masyarakat membuang sampah pada alor atau lahan yang tidak terpakai. Sampah-sampah yang dibuang anggota jemaat Sektor pison ada yang dapat terurai dan tidak dapat terurai.

Sampah-sampah yang tidak dapat terurai tersebut apabila dibuang pada suatu lahan akan menganggu atau merusak komposisi tanah dan fungsi tanah sebagai bidang resapan air dan juga dapat menganggu kehidupan flora dan faunna. Sampah yang tergolong ragam jenis ini misalnya: plastik, kaca, logam, dan keramik kalau di bakar dapat menyebabkan polusi udara. Hal ini di pacu karena tidak ada tempat pembuang sampah yg berada di sekitar tempat tingal penduduk atau dapat di pacu kerana tempat pembungan sampah yang jauh dari daerah pemukiaman warga setempat.

Berdasarkan Realitas yang terjadi maka, masalah tersendiri pada karakter peduli lingkungan bagi anak di Jemaat GPM Eden kudamati sektor pison adalah anak lebih suka membuang sampah di Alor seperti Kaleng, botol, dan logam. Karakter Anak yang terjadi Dalam Jemaat GPM Eden karena Peran keluarga dalam menumbuhkan karakter peduli lingkungan bagi Anak masih jauh dari apa yang diharapkan atau masih kurang jika dinilai dari sisiperan dan tanggung jawab sebagai orang tua untuk membentuk dan membangun karakter Anak yang baik. Kurangnya perhatian dan pendampingan orang tua terhadap anak inilah, yang mengakibatkan karakter anak merosot yang berdampak pada sikap dan tingkah laku dalam keseharian hidupnya, baik untuk diri sendiri maupun terhadap lingkungan dimana anak berada. Karakter seperti ini harus di dorong untuk mengalami pembaharuan diri, sehingga menjadi anak yang beretika, disiplin, dan berkarakter yang baik. Jadi bukan untuk harus dipengaruhi tetapi harus dapat memberi pengaruh kebaikannya kepada yang lain dalam hal ini lingkungan.

Berdasarkan hasil pengamatan penulis, ternyata peran orang tua yang diharapkan dapat menjadi contoh dan teladan bagi anak dalam keluarga belum dapat diwujudkan dengan baik. Karena Orang tua yang terlalu sibuk dan lebih mengutamakan pekerjaan sebagai pencari nafkah dari pada melakukan Pembina didalam Keluarga, sehingga dapat memberikan pengaruh buruk bagi perkembangan karakter anak. Banyak anak kristen yang sering bertindak sesuai dengan apa yang diinginkan oleh mereka seperti, Membuang sampah di alor, membakar Sampah disekitar pekarangan rumah, serta tidak membersihkan lingkungan. 


\section{Metode Penelitian}

Jenis penelitian ini adalah penelitian kualitatif. Bogdan dan Taylo mendefinisikan penelitian Kualitatif sebagai penelitian yang menghasilkan data deskriptif berupa kata-kata tertulis atau lisan dari orang- orang dan perilaku yang dapat diamati (Lexy Moleong, 2002:9). Secara umum penelitian kualitatif bertujuan untuk memahami (understanding) dunia makna yang disimbolkan dalam perilaku masyarakat menurut perspektif masyarakat itu sendiri. Dan penelitian Kualitatif adalah salah satu metode untuk mendapatkan kebenaran dan tergolong sebagai penelitian ilmiah yang dibangun atas dasar teori-teori yang berkembang dari penelitian dan terkontrol atas dasar empirik. Jadi dalam penelitian kualitatif ini bukan hanya menyajikan data apa adanya melainkan juga berusaha menginterpretasikan korelasi sebagai factor yang ada yang berlaku meliputi sudut-sudut pandang atau prose yang sedang berlangsung (Imam Suprayogo, 2001:7).

\section{Pembahasan}

Karakter merupakan nilai-nilai perilaku manusia yang berhubungan dengan Tuhan Yang maha Esa, diri sendiri, sesama manusia, lingkungan, dan kebangsaan yang terwujud dalam pikiran, sikap, perasaan, perkataan, dan perbuatan berdasarkan norma-norma agama, hukum, tata krama, budaya, dan adat istiadat. (http://tobroni.staff.umum.ac.id) Hal yang sama pun disampaikan oleh anak LT bahwa sikap manusia terhadap lingkungan berupa tindakan dalam kehidupan sehari-hari yang merupakan upaya untuk mencegah rusaknya lingkungan hidup. Pendapat lain juga di sampaikan oleh anak FR, ia mengatakan bahwa saya belum mengerti tentang karakter peduli lingkungan karenalingkungan keluarga saya tidak mengajarkan tentang peduli lingkungan, bahkan saya saja sering membuang sampah di Alor.

Berdasarkan pernyataan yang diterima oleh penulis dapat disimpulkan ada dua hal yaitu karakter anak remaja terkait peduli lingkungan hidup. Pertama, Anakremaja dalam Jemaat Eden Sektor Pison sebagian sudah memahami dengan jelas karakter mereka terhadap kepedulian lingkungan hidup. Kedua, Ada anak remaja yang belum memahami tentang peduli lingkungan hidup sehingga karakter mereka merosot yang menyebabkan mereka tidak peduli terhadap lingkungan hidup dengan membuang sampah pada Alor. Selain itu juga Karakter seseorang terbentuk karena kebiasaan yang dilakukan, sikap yang diambil dalam menanggapi keadaan, dan kata-kata yang diucapkan kepada orang lain. Karakter ini pada akhirnya menjadi sesuatu yang menempel pada seseorang dan sering orang yang bersangkutan tidak menyadari karakternya. Orang lainbiasanya lebih mudah untuk menilai karakter seseorang.

Menurut bijewidjajanto, kebiasaan seorang terbentuk dari tindakan yang dilakukan berulang-ulang setiap hari. Tindakan-tindakan tersebut pada awalnya disadari atau tidak disengaja, tetapi karena begitu seringnya tindakan yang sama dilakukan maka pada akhirnya seringkali kebiasaan tersebut menjadi refleks. Ada pula beberapa informan yang menyangga bahwa: sayapun adalah anggota jemaat yang membuang sampah di alor. Sebenarnya alor bukan tempat membuang sampah, saya sadar ketika membuang sampah sampah disana. Hanya saja hal ini sudah menjadi rutinitas kami setiap hari. Sehingga untuk mengubahnya agak terasa sulit. Perilaku ini bukan hal baru untuk kami yang tinggal dilingkungan dekat dengan alor, dan setahu saya, saya bukan orang pertama yang membuang sampah di Alor. Karena perilaku buang sampah di alor ini sudah dilakukan sejak dulu. Kami hanyamelanjutkan kebiasaan ini sampai sekarang.

Informan lain juga menanggapinya mau bagaimana lagi. Sejak dulu tidak ada yang menyediakan tempat untuk pembuangan sampah yang terdekat untuk dijangkau. Sehingga 
perilaku ini terus dipelihara oleh kami generasi penerus. Tetapi seharusnya cara ini harus dirubah, agar kami tidak lagi membuang sampah sembarangan di alor. Berdasarkan sanggahan beberapa informan diatas, dapat dipahami bahwa perilaku ini dipengaruhi juga oleh beberapa faktor lainnya sehingga perilaku membuang sampah sembarangan di alor telah menjadi rutinitas bagi anak remaja. Diantaranya ada faktor karena kebiasaan, kesadaran, pemahaman, dan jarak tempatpembuangan sampah terlalu jauh untuk dijangkau oleh mereka.

Terkait dengan perilaku keseharian ini, menunjukan bahwa lingkungan tempat tinggal jemaat mengalami krisis ekologi. Pada dasarnya terjadi akibat perilaku manusia yang tidak bijaksana dalam memperlakukan alam sebagaimana mestinya.Pemukiman rumah jemaat sektor pison yang mayoritasnya adalah daerah curam memungkinkan beberapa anak remaja jemaat sektor pison lebih memilih untuk membuang sampah di alor dibandingkan harus menempuh jarak yang jauh. Perilaku yang terjadi dalam konteks lingkungan jemaat ini mengambarkan bahwa sikap dan tanggung jawab terhadap alam yang telah diberikan kuasa tidak dipertanggungjawabkan dengan benar kepada sang pencipta. Dalam artian tampakjelas dalam realitas perilaku buang sampah yang dilakukan oleh anak remaja sudah sewenang-wenang terhadap alam. Atas dasar pemahaman dan kebiasaan itu, anak remaja menjadikan lahan kosong/alor sebagai tempat untuk membuang sampah. Ini berarti sudah sejak lama alor difungsikan dengan seenaknya oleh anak remaja, sama halnya dengan tindakan melanggar amanat Allah membawa dampak rusaknya hubungan manusia dengan alam, sehingga manusia menghadapi alam tidak lagi dalam konteks "sesama ciptaan" tetapi mengarah pada hubungan "tuan dan miliknya". Alor atau lahan kosong itu diperhatikan hanya dalam konteks kegunannya sebagai tempat untuk membuang sampah bukan untuk kelangsungan makhluk hidup lainnya.

Perilaku buang sampah sembarangan di alor sangat disadari akan menciptakan keadaan yang tidak nyaman. Hanya saja anak remaja seolah-olah mempelajarinya melalui pengalaman kehidupan yang terjadi secara natural. Anak remaja sadar ketika membuang sampah di Alor, akan mengakibatkan pencemaran lingkungan dan bahan mengancam satwa lainnya yang berada di temapat itu. Namun karena factor ketidak tersediaan tempat pembuangan sampah terdekat maka kesadaran remaja hanya muncul sebagai bentuk rasa saja, bukan sebagai suatu bentuk tindakan yang harus ditindaklanjuti dalam mewujudkan rasa tangungg jawab terhadap lingkungan yang harus dijaga dan dipelihara. Penulis menyadari bahwa perubahan perilaku buang sampah ini sangat sulit dan lambat, bahkan akan terasa sulit untuk diaktualisasikan. Namun sebagai orang kristen yang sudah dipercayakan oleh Allah untuk melakukan yang terbaik untuk alam dan lingkungan, sudah menjadi tugas bersama dalam mewujudkan panggilan kekristenan kita lewat perubahan perilaku yang harus dilakukan.

Selanjutnya untuk mendapatkan informasi terkait dengan pandangan tentang lingkungan hidup penulis memberikan pertanyaan tentang "apakah pentingnya lingkungan hidup yang sehat? Informan mengemukakan bahwa bagi anak remaja lingkungan hidup yang sehat itu penting karena lingkungan hidup sangat dibutuhkan oleh setiap makhluk hidup sebagai tempat kelangsungan hidupnya terkhususnya manusia, manusia memerlukan lingkungan yang sehat dan bersih. Selain itu ada juga yang berpendapat bahwa lingkungan yang kotor akan membuat kesehatan manusia terganggu dan mudah terserang penyakit. Pemahamanyang sama juga di sampaikan oleh informan bahwa lingkungan hidup merupakan penunjang bagi kelangsungan hidup manusia.

Berdasarkan hasil jawaban yang diuraikan diatas, maka dapat di jelaskan bahwa sebagaian besar anak-anak remaja di Jemaat Eden Sektor Pison sudah memahami tentang 
pentingnya lingkungan hidup yang sehat, bahwa dengan menjaga lingkungan yang bersih sangat penting untuk kesehatan, agar anak-anak dapat terhindar dari berbagai penyakit dan juga lingkungan yg bersih juga sangat penting untuk menumbuhkan karakter anak terhadap peduli lingkungan.

Selanjutnya untuk mendapatkan informasi tentang hubungan anak remaja dengan lingkungan hidup. Peneliti memaparkan teori dalam buku Etika bumi baru bahwa lingkungan hidup adalah lingkungan disekitar manusia tempat organisme dan anorganisme berkembang dan berinteraksi jadi lingkungan hidup tidak lain dari planet bumi ini. Sebenarnya manusia adalah bagian integral dari organisme tersebut, sekalipun bagian yang terkecil ini perlu ditekankan, sebab seringkali manusia seolah-olah bukan bagian dari lingkungan. Seolah-olah manusia bukan bagian dari bumi ini. Padahal namanya saja sama artinya dengan bumi (Jonathan schell, 1982:99). Namun manusia seringkali tidak dapat berinteraksi dengan lingkungan secara baik. Malah merusaknya sehingga menyebabkan bumi ini menjadi krisis ekologi.

\section{Faktor yang Mempengaruhi Karakter Remaja Peduli Lingkungan Hidup}

Adapun faktor-faktor yang menumbuhkan karakter anak remaja terhadap kepedulian lingkungan hidup antara lain: keluarga, komunikasi dalam keluarga, pendidikan orang tua yang lemah. Keluarga adalah inti utama dalam membentuk kepribadian anak, sebab merupakan hal yang sangat mendasar sehingga muncul pikiran-pikiran yang tidak sehat, anak pun dapat mengikuti jejak dari sang orang tua tersebut. Komunikasi orang tua dan anak merupakan sarana yang di butuhkan untuk dapat membentuk karakter anak. Akan tetapi akibat aktivitas oaring tua yang sibuk akibat pekerjaan mereka sehingga komunikasi yang terbangun jarang terjadi. Itu semua di akibatkan karena saat anak masih tidur orang tua telah berangkat ke kantor dan saat pulang dari kantor anak di dapati telah beristirahat, sehingga tidak ada pembinaan yang terjadi di dalam keluarga. Pendidikan orang tua adalah faktor yang mempengaruhi proses pendidikan anak dalam keluarga. Orang tua yang kurang menyadari arti pembinaan yang sebenarnya akan berakibat buruk terhadap proses perkembangan kepribadian anakdisekolah, keluarga, bahkan ditengah masyarakat luas. Orang tua sebagai pencetus ide-ide baru yang kreatif akan dicontohi anak.

\section{Pentingnya Peran Keluarga Menumbuhkan Karakter Peduli Lingkungan bagi Remaja}

Semua anak tumbuh dan berkembang dari keluarga masing-masing. Jika seorang anak tumbuh didalam keluarga bermasalah, maka otomatis akan berdampak bagi karakternya. Apakah dampak yang ditimbulkan positif atau negatif. Karena itu betapa pentingnya peranan orang tua dalam membentuk karakter anak menjadi positif yaitu lewat cara membimbing, mendidik, mengasuh, dan mendekatkan anak itu kepada Tuhan dengan tujuan supaya anak dapat berhasil dan membanggakan kedua orang tuanya. Banyak anak-anak yang sukses melewati tahap-tahap perkembangan hingga secara otomatis membanggakan keluarganya. Meskipun banyak hal dan rintangan Yang harus dilewati. Pada intinya dari keberhasilan yang dicapai oleh anak ini sangat berkaitan dengan peran yang dimainkan oleh orang tuanya.

Sudirman (1998:7) mengatakan bahwa orang tua adalah teladan pertama bagi pembentukan karakter anak. Keyakinan, pemikiran, perilaku ayah dan ibu sendirinya memiliki pengaruh yang sangat besar terhadap pemikiran dan perilaku anak, karena kepribadian manusia muncul berupa lukisan-lukisan pada berbagai ragam situasi dan kondisi dalam ling- 
kungan keluarga. Orang tua berperan sebagai faktor pelaksana dalam mewujudkan nilai-nilai keyakinan dan presepsi budaya sebuah masyarakat ayah dan ibulah yang harus melaksanakan tugasnya dihadapan anaknya. Khususnya ibu yang harus memfokuskan dirinya dalam menjaga akhlak, jasmani, dan kejiwaannya. Berikut ini ada beberapa peran orang tua dalam menumbuhkan karakter peduli lingkungan bagi anak remaja: saling menghormati antara anak dan orang tua, pola komunikasi yang dijalankan dalam keluarga, mengadakan perkumpulan dan rapat keluarga, orang tua perlu memasuki dunia anak.

\section{Orang tua Menumbuhkan Sikap Peduli Lingkungan bagi Remaja}

F.C. Lewier (1981: 6) dalam ceramahnya mengatakan bahwa orang tua sudah harus mendapat perhatian pertama dan utama. Sebab merekalah pendidik dan pembina utama dan pertama dalam keluarga nayatalah betapa pentingnya keluarga dalam mempersiapkan (membina, mendidik, membimbing), anggota keluarganya untuk siap menghadapi tantangan hidup yang ada. Perhatian orang tua terhadap anak seharusnya lebih diutamakan dibandingkan pekerjaan orang tua yang ditekuni untuk kebutuhan ekonomi keluarga setiap hari.

Hal ini sangat penting diutamakan oleh orang tua sebab bagi keluarga-keluarga Kristen mendidik anak adalah sesuatuyang sangat penting seperti yang ditekankan oleh Alkitab bahwa "apa yang ku perintahkan kepadamu pada hari ini haruslah engkau perhatikan, haruslah engkau mengajarnya berulang-ulang kepada anakmu dan membicarakannya apabila engkau duduk dirumahmu, apa engkau sedang dalam perjalanan, apabila engkau berbaring, apabila engkau bangun, atau ayat yang sering dipakai anak merupakan simbol kerajaan Allah, atau kitab mazmur "seperti anak-anak panah ditangan pahlawan, demikian anak-anak pada masa muda. Dari gambaran di atas maka, peran orang tua sangatlah penting dalam menumbuhkan karakter dari anak. Gambaran diatas hendak menunjukan bahwa orang tua memerlukan karakter dasar dalam proses mendukung kepribadian anak. Untuk itu Karakter orang tua dalam menumbuhkan karakter anak remaja sebagai berikut: orang tua sebagai mediator, orang tua sebagai motivator, orang tua sebagai fasilitator, orang tua sebagai inisiator, implikasi PAK.

Pendidikan Agama Kristen pada dasar merupakan usaha sadar Gereja yang dilakukan secara terencana dan sistematis oleh gereja untuk mengantarkan umatnya kepada pengenalan yang sempurna akan Allah dan karya-karyanya bagi dunia. Karena itu pendidikan adalah satu alat pelayanan dan kesaksian gereja sebagai alatpelayanan dan kesaksian gereja maka pendidikan yang diberikan oleh gereja kepada warga mencakup seluruh masalah-masalah yang melilit kehidupan warga gereja.

Dewasa ini gereja dipandang dalam membangun refleksi-refleksi atau fokus pengajarannya hanya berfokus pada keselamatan manusia, padahal bahwa keselamatan yang dikerjakan oleh Yesus Kristus mencakup semua ciptan secara utuh, sampai unsur Alam yang paling kecil sekalipun, baik abiotic maupun biotik. Realitas menunjukan bahwa perkembangannya gereja dalam pengajarannya mengabaikan keselamatan pada keutuhan ciptaan Allah dan tanggung jawab manusia dalam kaitan dengan menjagadan mengelola bumi. usaha pelestarian lingkungan hidup tidak hanya merupakan tanggung jawab pemerintah saja, melainkan tanggung jawab bersama antara pemerintah dengan masyarakat bahkan juga gereja.

Lewat penerapan nilai-nilai Pendidikan agama Kristen yaitu nilai tanggung jawabdan nilai moral, maka manusia diajarkan untuk bertanggung jawab atas alam dan bukan untuk merusak. Dalam Kejadian 1:28 manusia diberikan mandat oleh Allahuntuk menguasai dan menaklukan seluruh isi bumi (hewan ternak, ikan, ungas, tumbuh-tumbuhan, dan lain-lain) didalam keselarasan dan keutuhan yang saling menghidupkan sesuai kasih karunia pemeliharaan Allah. 
Lingkungan hidup merupakan sumber daya alam atau kekayaan alam yang sangat dibutuhkan oleh manusia untuk memenuhi kebutuhan hidup yang jumlahnya sangat terbatas. Jika manusia selalu mengotori lingkungan, menebang pohon sembarangan, membakar sampah. bisa jadi sumber daya alam yang berada didalamnya untuk memenuhi kebutuhan kehidupan kita sehari-hari akan hilang.

Tujuan Allah memberikan mandat kepada manusia untuk menguasai dan menaklukan alam dalam arti mengusahakan dan memelihara alam untuk mensejahterakan hidup manusia, menjaga keharmonisan dengan alam untuk memuliakan Allah, tujuan itu dilaksanakan dan tercapai bila manusia menjalankan mandate kepemimpinanya sebagai panggilan sehingga melaksanakan dengan penuh tanggung jawabmengelola, memelihara alam yang dipercayakan kepadanya, alam harus diperlakukan dengan adil dan tidak boleh diboroskan dan dirusakan untuk kesenangan hati manusia saja, juga tidak untuk keuntungan ekonomi belaka, tugas tersebut dinyatakan dalam berbagai upaya mencegah kerusakan dan pengotoran lingkungan hidup.

Oleh karena itu sebagai anggota jemaat mustinya memahami bahwa alam ciptaan ini merupakan pemberian Allah yang harus dijaga dan dilindungi agar selalu mendatangkan kebaikan, sebab bumi ini melambangkan kehadiran Allah dalam arti menyatakan kebaikan hati Allah kepada manusia oleh karena itu harus dihargai dengan sikap dan perilaku yang baik terhadap alam dengan menjaga lingkungan sektor pison agar terhindar dari Lingkungan yang kotor.

Yang harus dikembangkan adalah agar anggota Jemaat GPM Eden Sektor pison memiliki kepekaan khusus terhadap keadaan Lingkungan hidup sekitar, hidup yang menghargai dan menghormati perlu ditanam dan dikembangkan dalam kehidupan bersama sebagai ciptaan Tuhan. Manusia tidak dapat begitu saja menghabiskan kekayaan alam tanpa memikirkan kebersamaan dengan seluruh jagat raya, manusia hanyalah bagian kecil dari seluruh sistem ekologis maka manusia seharusnya bertanggung jawab atas tindakannya terhadap diri, sesama, dan lingkungan hidup.

Dengan demikian tanggung jawab berteologi secara ekologi dimana proses PAK terjadi serempak ialah bahwa setiap orang dipanggil untuk bertanggung jawabterhadap lingkungan dan alam sekitarnya. Sebab ekosistem yang didalamnya terdapat tumbuh-tumbuhan, binatang, alam, dan manusia adalah merupakan bagian dari ciptaan Allah yang seharusnya dijaga dan dipelihara guna membangun hubungan yang harmonis diantara berbagai komponen yang ada. Manusia seharusnya tidak memandang alam sebagai fakta biologis fisik atau objek, tetapi terutama sebagai keberadaan yang menjadi cerminan sang pencipta, yaitu Allah. Itutidak berarti bahwa alam itu semu dan hanya ada sebagi bayang-bayang Allah, tetapi manusia harus menghargai alam sebagai karya Allah dan karunia.

\section{KESIMPULAN}

Implementasi pembentukan karakter seoarang anak harus didukung oleh semua lembaga pendidikan termasuk lingkungan keluarga. Keluarga adalah unit terkecil dari masyarakat yang terdiri atas kepala keluarga dan beberapa orang yang terkumpul dan tinggal di suatu tempat di bawah suatu atap dalam keadaan saling ketergantungan. Pada keluarga inilah, Anak mendapat didikan dari orang tua menuju ke arah perkembangannya. Keluarga bagi seorang anak merupakan lembaga pendidikan non formal pertama, dimana mereka hidup, berkembang, dan matang. Keluarga juga memiliki peran penting baik dari segi pengetahuan dan Pendidikan karakter tetapi merupakan tempat pembinaan bagi anak dalam menumbuhkan karakter baik 
secara moral maupun krakter dalam mencintai lingkungan yang merupakan tempat mereka bertumbuh dan berkembang.

\section{REFERENSI}

Bahrudin Supardi, (2009) Berbakti Untuk Bumi, Bandung:

Bijewidjajanto"Pengertian pendidikan karakter" Yogyakarta:Pustaka Belajar, 2003, hal 4.

Daryanto \& Darmiatun S, (2013) Implementasi Pendidikan Karkater di Sekolah, Yogjakarta: Gava Media.

Esti Apriliyana, (2016) Kajian Teori Peduli Lingkungan Sekolah, Jurnal IlmuPengetahuan Sosial.

H. Mahmud, (2015) Pendidikan Lingkungan Sosial dan Budaya, Bandung: PTRemaja Rosdakarya.

Imam Suprayogo, Tobroni, ( 2001) Metode penelitian Sosial agama cet. 1,Bandung : Remaja Rosdakarya.

Jonathan schell, the faith of the earth, New York :avon books, 1982 hlm.99Jesika Manusiwa, (2017) Sadar Lingkungan, SKRIPSI STAKPN, Ambon .

Lexy J, Moleong, (2002) Metodologi penelitian kualitatif, Bandung: RemajaRosdakarya. Mathew. B. Milles, (1992) Analisa data kualitatif, Jakarta, Bumi aksara, 15-19 Purwanto dalam Binti Maunah, Landasan Pendidikan, Yogyakarta: Sukses Offset, 2019.

Rachmad K.dwi Susilo, (2009) Sosiologi Lingkungan, Jakarta: Rajawali Pers.

Http, ( 1 Juni 2020) Peduli Lingkungan Peduli, blogspot.co.idHttp, ( 1 juni 2020) Respository, ump.ac.id, 14543 ESTI

Tobroni "Pendidikan karakter dalam perspektif Islam " http://tobroni.staff.umum.ac.id 